\title{
Brazilian Indigenous People's Struggle for an Intercultural, Specific, Differentiated School
}

\author{
José Licínio Backes \\ PPGE, UCDB, Campo Grande, Brasil \\ Email: backes@ucdb.br \\ Received 15 September 2015; accepted 11 January 2016; published 14 January 2016 \\ Copyright (c) 2016 by author and Scientific Research Publishing Inc. \\ This work is licensed under the Creative Commons Attribution International License (CC BY). \\ http://creativecommons.org/licenses/by/4.0/ \\ (c) (i) 0 pen Access
}

\begin{abstract}
This paper analyzes the Indigenous people's struggle for an intercultural, specific, differentiated school intended for the valorization of their culture and identity. Aiming to catechize and adapt Indigenous peoples to the western culture, settlers introduced school education as a means to make the Indians give up their identities and integrate them into the national culture. This paper evidences that the Indians have opposed the colonial school right from the start, and by means of struggle and organization, they obtained the right to an intercultural, specific, differentiated Indigenous school. However, obtaining this right had not put an end to their struggle, as the end of colonial school did not mean the end of coloniality.
\end{abstract}

\section{Keywords}

Indigenous School, Coloniality, Identity

\section{Introduction}

The struggle for a school oriented towards cultural diversity by questioning the school that values the hegemonic culture has characterized the last decades in Brazil. In this struggle, the Indigenous movements have stood out in the construction of an intercultural, specific, differentiated school concerned with both the valorization of their culture and the affirmation of their identities.

This paper ${ }^{1}$ reflects on this process and argues that Indigenous people are protagonists in such struggle. In Indigenous communities, the discussion about kinds of school and their purposes has been intense, in an attempt to undo the marks left by the colonial matrix and radically re-signify the meaning of school.

${ }^{1}$ Version reviewed and translated from the paper published in Portuguese in Revista Interações (UCDB). 
The paper is organized in two parts. In the first part, we pointed out the different phases of Indigenous schooling and the struggle of Indigenous people that led to the recognition of their right to an intercultural, specific, differentiated school. It shows that such struggle is ongoing, as the end of colonialism did not mean the end of coloniality. In the second part, we present some Indigenous university students' speeches and articulate their discourse with ideas formulated by theorists of interculturality and Indigenous school.

\section{From the Colonial School to the Intercultural Indigenous School}

Since the colonization period, Indigenous peoples have struggled to defend their identities in multiple ways. Since the European invasion, the school has had a central role in the production of Indigenous identities-firstly as something imposed by the settlers in order to eliminate those identities, and currently as a means to strengthen them in an initiative led by Indigenous people.

Supported by Candau \& Russo (2010), we can say that there are four distinct moments in the Indigenous education in Brazil. The first started in the colonial period and lasted until the first decades of the $20^{\text {th }}$ century; it is characterized by the "[...] explicit ethnical-centric violence of imposing the hegemonic culture on Indigenous populations" (Candau \& Russo, 2010: p. 155), i.e. the school was a means to eliminate the Indians, their culture, their language. The second moment, from the first decades of the $20^{\text {th }}$ century to the 1970 s, is characterized by cultural assimilation, aimed at constructing a homogeneous State. From this perspective, the Indigenous groups should be assimilated into the national culture to be part of the labor force, as the country was then entering into the urban/industrial era. Bilingual schools emerged in that period, but the native language was often seen as a transition element to favor cultural assimilation. The third moment, along the 1970s and 1980s, is characterized by the emergence of alternative experiences led by community leaders and the Progressive Catholic Church, concerned with strengthening the Indigenous culture and identity. The fourth moment started at the end of the 1980s and is still in progress; it is characterized by the defense of an intercultural, bilingual, differentiated school, and proposes a dialogue between cultures. Both Indigenous people and researchers in this field have pointed the country's 1988 Constitution as a decisive landmark for the right to specific, differentiated education, including mother tongue teaching and typical learning processes. We should highlight the fact that this was not a gift conceded by the Brazilian State; rather, it was a conquest by the Indigenous movement. With the Constitution and the legal apparatus it has provided, new possibilities have emerged considering the cosmologies of every people, thus contributing to the process of identity affirmation.

It is worthy of note that, despite all the control mechanisms, the assimilation strategies and violence committed by the Brazilian State to "help" Indigenous people to "be integrated” into the national society, "[...] the Indians that 'survived' did it exactly because they kept their cultural difference and were not 'diluted' in the cauldron of the national society” (Camargo \& Albuquerque, 2003: p. 343).

The school-initially an imposition of colonizers on the Indigenous peoples and as such at the service of interests of the colonizing project-can be regarded as one of the central institutions for assimilation of the Indigenous culture, hence marked by consistent practices of identity negation, particularly the prohibition of the native language. However, owing to the force, struggle and protagonism of Indigenous peoples, the school has become a space-time of other ways to be in it, other ways to educate in it, other ways to relate with it, other ways to approach knowledge, other ways to address epistemologies, other ways to produce identities. The comprehension of how this process occurred involves acknowledging men and women's inexhaustible power of re-signification and creation: "by carefully observing life in the village and activities performed in the school, we can gradually see the power to create other ways of school expression and action” (Bergamaschi, 2007: p. 201).

Perhaps we could say that the intercultural, specific, differentiated Indigenous school is the most visible form of human potential to transgress, re-signify, and hybridize practices, institutions and forms of knowledge/power. The authoritarian, assimilationist, homogenizing western school was or has been turned into a meaningful space/ time for the affirmation of Indigenous ethnic groups. One cannot ignore the importance and dimension of this achievement, especially considering the extremely adverse context in which it occurred.

The implementation of the colonizing process, as Walsh (2010) has argued, was intended to subordinate every cultural difference. There was no room for other rationales, other epistemologies, other ways of being, knowing and living. Far from disappearing at the end of the colonial period, this process still marks our way of thinking and producing knowledge. The end of colonialism neither meant the end of the imposition of western values on Indigenous peoples, nor the end of the imposition of those values on anyone who did not share them, thus generating “[...] repeated trauma, violence, and negation of the other” (Skliar, 2003: p. 111). 
The process occurring after the colonial period has been called coloniality and has lasted up till now in the $21^{\text {st }}$ century: "Anyway, the coloniality of power [...] was and is active, as it is part of the global context within which processes affecting every concrete space of domination take place” (Quijano, 2002: p. 13). More specifically, we still live in spaces/times of coloniality of knowledge, power, worldview and ways of being. If for a long time parameters were Eurocentric, Walsh (2010) has stated that nowadays there is a "Euro-USA-centric" imposition, with characteristics that remind us of the colonial project, i.e. the difference is still seen as something to be eliminated, corrected, assimilated or ignored.

Based on Walsh (2010), in order to question, subvert and displace coloniality, we can say it is important to act on three dimensions: intercultural, inter-epistemic and decolonial. These three dimensions mix, meet, intersect, that is, they are articulated. Considering the articulation of those dimensions has " $[\ldots]$ the considerable advantage of enabling us to think of specific practices (articulated around contradictions which do not all arise in the same way, at the same point, in the same moment) can nevertheless be thought together” (Hall, 2003: p. 152).

Regarding the intercultural dimension, it is worth emphasizing that, according to Candau \& Russo (2010), there is a consensus in the literature and between researchers of interculturality that this term emerged in Latin America with the Indigenous school education. It has been seen as an "[...] ethical, political [component] for the construction of democracies in which cultural acknowledgement and redistribution are regarded as indispensable to social justice” (Candau \& Russo, 2010: p. 164). Through the intercultural dimension, we have learned, particularly with Indigenous peoples and other subalternized peoples, to question the Nation-State and the idea of national culture, not only with the aim of marginally including the Indigenous and African-Brazilian cultures, but positioning them as constitutive and central, thus creating new conditions of thinking, knowing, being and living. The Indians have consistently encouraged us to reflect "[...] on other times and spaces, what means to be living, the possibility of constructing other identity narratives. They have also stimulated us to think of how to resist, subvert, and re-signify practices of colonization and subordination” (Backes \& Nascimento, 2011: p. 26).

Concerning the inter-epistemic dimension, it has led us to make efforts to transgress the Euro-USA-centric epistemological marks that still typify our ways of thinking and producing knowledge, as well as our universities. To produce epistemologies that are not the expression of a unique logic, especially the logic of domination and exclusion of difference, it is fundamental to incorporate the knowledge of social movements, particularly the Indigenous ones. We should pay attention to the plurality of subjugated knowledge, logics and rationales in an intellectual-political effort to create relationships, articulations and convergences among them (Walsh, 2010).

Finally, as to decolonial dimension, it is crucial to show that both in the past and in the present, there was/ there is an effort to challenge the colonial matrix of power and domination. In this sense, it is necessary to evidence that: a) although white, male, heterosexual social identities are still hegemonic, they have always been contested and subverted, and a number of other identities are equally legitimate; b) despite all the physical and symbolic violence committed to dehumanize Indigenous and black people, there are multiple ways of humanly being and existing; c) despite the imposition of the modern, positivist western epistemology as the only valid one, there is epistemic plurality and, even though this is not recognized by the universalizing, totalitarian epistemology, it responds better to the challenges posed by those peoples; d) despite the mechanisms of control and the historical, systematic negation of ancestral spiritual foundations of Indigenous peoples, these are still present, showing other possibilities of establishing relationships with nature and making sense of the world. In sum, as Walsh (2010) has claimed, challenging the colonial matrix of power and domination by promoting decolonization involves questioning the superiority of the white, male, heterosexual identity and its ontological-existential, cosmological superiority.

As we have stated, those dimensions are articulated. Therefore, they can combine in multiple ways, contributing to decolonization, the production of another thought and the strengthening of a critical intercultural education (Walsh, 2009).

Hereafter, we will argue that the Indians have shown other possible forms of power, knowledge, being and living. In the present context, they still challenge and subvert the colonial matrix and do that mostly through the radical re-signification of an institution: the school, and more specifically the intercultural, specific and differentiated school.

In order to construct our argumentation, we could resort to our experience with stricto sensu Indigenous students for more than eight years to show how much they are concerned with the Indigenous school; they have hybridized knowledge, consistently shown their collective bonds, affirmed their identities and culture, and resisted the colonial matrix. We could also resort to a number of dissertations presented by Indigenous students fo- 
cusing on Indigenous education and concerned with interculturality and the valorization of their culture and language. All these paths would be promising, but in this paper, we have opted to structure our arguments considering students attending teaching courses who answered semi-structured interviews.

We interviewed six Indigenous students from different teaching courses and ethnic groups from the State of Mato Grosso do Sul. The students attended a private university. In order to guarantee their anonymity, we will refer to each of them with the use of letters and will not provide identification data.

In our view, having undergraduate Indigenous students as research subjects may contribute to show to which extent the Indians are concerned with an intercultural, specific, differentiated school and how much this kind of school is present in the reflections in their communities. This concern has not resulted from the influence of outside educators/researchers, as the paper could cause one to think if it were based on strict sensu experience and dissertations written by Indians, as these studies have been produced in the context of a Research Line with a focus on Indigenous education and cultural diversity.

\section{Deconstruction of the Colonial Matrix by Means of the Indigenous School}

As we have already highlighted in this paper, in the current context, the Indigenous school, in which the Indians have been protagonists, has had a relevant role in the deconstruction of the colonial matrix. As Walsh (2010) has stated, if we consider that this colonial matrix is grounded on the alleged superiority of western power and ways of being, living and knowing, among other things, we can infer that the most concrete way for the Indigenous school to subvert the colonial matrix is through the affirmation of ethnical identity. The Indians themselves do not see this ethnical identity as something fixed and essential, but rather as either the result of social and cultural relationships, including relationships with non-Indians, or the result of their equally dynamical worldview: "the worldview of Indigenous peoples is not static, let alone essentialist and pure. As any other society, [...] they also change, reinvent themselves all the time and will know how to reinvent themselves when faced with new events, and the school is one of them" (Bergamaschi, 2007: p. 201). In this process of affirmation, the native language takes on a central role together with the valorization of traditional knowledge, learning processes and worldviews.

In this sense, we highlight that the Indians are totally committed to their school and have fought to keep it far from vestiges of the colonial school. In the research carried out with university students of different ethnical groups and courses, all of the respondents showed this kind of concern. They have left their communities to attend university with the strong commitment of coming back to offer intercultural education.

The Indians themselves produce that intercultural education, since the courses they attend convey western knowledge, but they establish a dialogue between this knowledge and their traditional knowledge, re-signifying them to turn them into something favorable to the Indigenous identity. It is "[...] the Indigenous culture interacting with the non-Indigenous society" (Student $\mathrm{A}^{2}$ ). Such interaction occurs in alignment with the concern about community and culture: "We pick out what is good for the Indians from what is taught all over the country and we also address the issue of Terena culture, Terena games, activities performed by Terena women, Terena men” (Student B ${ }^{3}$ ).

In the interview, this Physical Education student said that the course emphasizes competition, but this is not part of his culture: "In the Indigenous school, I can't see any competition. [...] I have worked with several cooperative games, not only with boys, but also with boys and girls together. [...] I have worked with cooperative games to avoid competition” (Student B). He problematizes the competition and shows that developing physical activities intended for collaboration and cooperation is important to his people. This kind of game contributes to the strengthening of collective bonds and community links. Unlike Physical Education in non-Indigenous schools, which excludes less skillful students, he proposes games in which everyone can participate: "We try to include the ones who don't play sports, the least skillful” (Student B).

Student B also questions Provinha Brasil ${ }^{4}$, because it is based on general knowledge and disregards Indigen-

${ }^{2}$ Terena ethnicity, male, 19 years old, $2^{\text {nd }}$ term of the Physical Education course. He has not worked as a teacher yet. "Terena people lived in the Chaco region in Paraguay and arrived in Brazil in the late seventeenth century. They actively participated in the Paraguay War; when the war was over, they lost their lands to farmers, to whom they worked under a regime of servitude. In the early twentieth century, there were the first demarcations of land for Terena people” (Pavan, Lopes, \& Backes, 2014: p. 164).

${ }^{3}$ Terena ethnicity, male, 27 years old, $6^{\text {th }}$ term of the Physical Education course. He works as a Physical Education teacher of the final grades in basic education at the indigenous school in his community.

${ }^{4}$ Provinha Brasil is a test applied to $2^{\text {nd }}$ grade children attending Brazilian public schools. It aims to assess Portuguese and Mathematics knowledge. 
ous knowledge, thus contributing to create a negative image of the Indigenous school: "I'm against Provinha Brasil, which evaluates knowledge conveyed by schools in Brazil. [...] Our school performance is below the average, out of the standards, as they say. But they haven't realized that education is different there”.

Student $C^{5}$ also questions the inadequate management by the State, which creates guidelines that often have marks of coloniality. She shows how the community has questioned those guidelines and subverted them when they run counter Indigenous students' interests: "when a guideline is above the students and far from their reality, it is useless. The community, the school... The community is aware of that".

According to some authors (Candau \& Russo, 2010; Candau, 2011, 2012; Walsh, 2009, 2010; Bergamaschi, 2007; Backes \& Nascimento, 2011), the students are concerned with the dialogue between cultures through intercultural education. "The school should design work plans to attend students in their differences and search for equality within those differences" (Student C). "In the Indigenous school, we need to work with both the traditional knowledge and the urban, global knowledge" (Student B). "The school can work with several cultures" (Student A). "We need to know their culture, but without disregarding our Terena culture" (Student $\mathrm{F}^{6}$ ). "There shouldn't be prejudice, because everyone is different. Everyone should respect each other's culture" (Student $\mathrm{D}^{7}$ ). "We have been struggling to create a school that respects cultures, the Indigenous culture. We must try. We have succeeded" (Student $\mathrm{E}^{8}$ ).

It is interesting to see that the Indigenous discourses are related to principles that researchers in the area of intercultural education have consistently advocated. Candau (2011), on approaching the cultural diversity and the importance of intercultural education, has pointed out: "Multiple issues have been raised and made visible by social movements which have denounced injustices, inequalities and discriminations, claiming for equal access to goods and services as well as political and cultural acknowledgement” (Candau, 2011: p. 241). Candau (2011, 2012) has often evidenced the need of struggling prejudices and considering different cultures. The author has both questioned the hegemony of modern culture and evidenced the need to articulate difference and equality, as Student C pointed out: “[...] within those differences, we search for equality”. For Candau (2012), equality and difference are necessarily part of intercultural education; they do not oppose each other, they are part of the same struggle: "I think that today it is not possible to work on issues related to equality without including difference; likewise, we can’t address difference disconnected from equality affirmation” (Candau, 2012: p. 239).

Candau (2012: p. 237) has also argued that in order to potentialize the process of school learning, "[...] in the perspective of guaranteeing the right to education, we will have to affirm the urgency to work on issues related to the acknowledgement and valorization of cultural differences in school settings". This perspective is very important to the Indigenous students, who see in the presence of different cultures a possibility of dialogue that does not generate prejudice and favors mutual respect.

In the same way that it is possible to perceive the approximation between the Indigenous students' reflections and Candau's (2011, 2012) ideas, such approximation also occurs in relation to Walsh's (2009, 2010) thoughts. For this author, as well as for Candau (2010, 2011), intercultural education should be constantly concerned with avoiding " $[. .$.$] exclusion, negation and ontological, epistemic-cognitive subalternization of racialized groups and$ subjects" (Walsh, 2009: p. 23). She has also claimed that interculturality is currently present in several State policies in Latin America, but often ends up meeting the interests of the very domination system, i.e. coloniality.

In this sense, the author has argued in favor of a critical interculturality concerned with a systematic disruption of the structures of discrimination, racism and exclusion to contribute towards both the education of subjects able to live with cultural difference and the construction of a society with social justice and equality. Such critical intercultural education, according to Walsh (2009), has not been accomplished yet; rather, it is a project to be daily constructed by the subalternized groups, which reminds Student E's speech when he said that they are struggling for a school that respects the differences and they have succeeded.

We can also state that the Indigenous students' discourses meet what researchers of Indigenous schools have

${ }^{5}$ Terena ethnicity, female, 39 years old, $8^{\text {th }}$ term of the Pedagogy course. She works as a teacher of Indigenous Art and Culture of the early grades in basic education at a non-indigenous school.

${ }^{6}$ Terena ethnicity, male, 27 years old, $7^{\text {th }}$ term of the Physical Education course. He works as a Physical Education teacher of all basic education grades at the indigenous school in his community.

${ }^{7}$ Terena ethnicity, female, 34 years old, $2^{\text {nd }}$ term of the Pedagogy course. She works on a social project for eradication of child work; the project is aimed at Terena children and functions during non-school hours.

${ }^{8}$ Kadiwéu ethnicity, male, 23 years old, $6^{\text {th }}$ term of the History course. He has not worked as a teacher yet. "Kadiweu people belong to the Mbaya branch and did not live in Brazil. They have come from the Chaco regions of Paraguay and Argentina. They were nomadic before becoming sedentary in Brazil. They had a warrior tradition and used to incorporate children, youths and adults from other peoples (Africans, Europeans) who were captured during the wars, which are no longer part of their culture” (Pavan, Lopes, \& Backes, 2014: p. 164). 
pointed. Bergamaschi \& Medeiros (2010: p. 61), in a paper describing the Kaiagang Indigenous school, say that the school has enabled "[...] Indigenous peoples to struggle more symmetrically for their rights by learning the western life system, but keeping and stating their own education methods”. In reference to the Indigenous school in Guarani villages, the authors have shown it has become different from the western school in small daily gestures, “[...] supported by the characteristics of their traditional education-curiosity, observation, imitation and respect, among other attributes responsible for the construction of a Guarani person. They take hold of the school and make it their own”. Gomes (2006: p. 325), studying Xakriabá schooling, shows it is deeply connected to the way they "[...] interpret the very school experience and the meaning they will give to school in the process of affirmation of their own identity and guarantee of the right to a differentiated school”. Camargo \& Albuquerque (2003: p. 359), who analyzed the process developed by Xavante to have a specific, differentiated Indigenous school, say that some of the hindrances the Indians have faced are "[...] the existence of a RCNEI, the difficulties to disrupt the rigid non-Indian calendars, the didactic material designed under strong non-Indian influence”.

Therefore, we have noticed an articulation between discourses of Indigenous students, researchers of intercultural education and researchers of Indigenous school, but Indigenous people still play the main role. They are permanently affirming their identities and questioning coloniality.

\section{Final Remarks}

We would like to mention Bhabha (1998), who said that subalternized knowledge penetrated hegemonic knowledge and in this process ended up subverting the very hegemony and undermining its strength. We think that Indigenous peoples have been able to do that. As Bergamaschi (2007) has pointed out, an attentive look reveals the specificities of the Indigenous school and how much of its culture, worldview and knowledge is presented in it.

In this sense, we reiterate some specificities that our effort to have an attentive look has shown a necessary effort, as we are still immerse in coloniality, although we try to struggle it. We can highlight the questioning of competition and the valorization of cooperation; the questioning of guidelines when they do not meet the Indigenous interests; the criticism to Provinha Brasil; the defense of the interaction between cultures; the valorization of the traditional knowledge, but in a dialogue with the global knowledge; and the importance of approaching several cultures at school.

Such specificities become more significant when we consider, as we have attempted to do in this paper, the historical relationship between school and Indigenous peoples. They show the resistance, the struggle and the strength of the Indigenous peoples in the defense of their knowledge, ways of being and living, by not bending to the colonial matrix and evidencing that other knowledge is possible, as well as other ways of being and interpreting the world.

\section{References}

Backes, J. L., \& Nascimento, A. C. (2011). Learning to Listen to the Voices of Those Who Live at the Ethnical-Cultural Exclusion Borders: A Daily Decolonial Exercise. Série-Estudos, 31, 25-34.

Bergamaschi, M. A. (2007). Indigenous School Education: A Particular Way of Recreating School in Guarani Villages. Cadernos Cedes, 27, 197-213.

Bergamaschi, M. A., \& Medeiros, J. S. (2010). History, Memory and Tradition in Indigenous School Education: A Kaingang School Case Study. Revista Brasileira de História, 30, 55-75. http://dx.doi.org/10.1590/S0102-01882010000200004

Bhabha, H. (1998). The Location of Culture. Belo Horizonte: UFMG.

Camargo, D. M. P., \& Albuquerque, J. G. (2003). The Xavante Pedagogical Project: Tensions and Ruptures in the Intensity of the Curriculum Building. Cadernos Cedes, 23, 338-366.

Candau, V. M. F. (2011). Cultural Differences, School Routine and Pedagogical Practices. Currículo sem Fronteiras, 11, 240-255.

Candau, V. M. F. (2012). Differences culturelles, realite interculturelle et education pour les droits humains. Educação $e$ Sociedade, 33, 235-250. http://dx.doi.org/10.1590/S0101-73302012000100015

Candau, V. M. F., \& Russo, K. (2010). Interculturallity and Education in Latin America: A Plural, Original and Complex Construction. Diálogo Educacional, 10, 151-169.

Gomes, A. M. (2006). The Process of Schooling among the Xakriabá People: An Exploration of Alternative Forms of Analysis in the Anthropology of Education. Revista Brasileira de Educação, 11, 316-375. 
http://dx.doi.org/10.1590/S1413-24782006000200010

Hall, S. (2003). Of Diaspora: Identities and Cultural Mediations. Belo Horizonte: UFMG.

Pavan, R., Lopes, M. C. L. P, \& Backes, J. L. (2014) The Construction of an Intercultural Dialogue with Indigenous by NonConventional-Action-Research. Acta Scientiarum. Education, 36, 163-173.

Quijano, A. (2002). Coloniality, Power, Globalization and Democracy. Revista Novos Rumos, 17, 4-25.

Skliar, C. (2003). (Unlikely) Pedagogy of Difference: What If the Other Weren't There? Rio de Janeiro: DP\&A.

Walsh, C. (2010). (Inter) Cultural Studies from a Decolonial Perspective. Revista Tábula Rasa, 12, 209-227.

Walsh, C. (2009). Critical Interculturality and Decolonial Pedagogy: In-Surgir, Re-Existing and Re-Living. In. V. M. Candau (Ed.), Intercultural Education in Latin America: Between Conceptions, Tensions and Proposals (pp. 12-43). Rio de Janeiro: 7 Letras. 